\title{
Character strengths of adolescent survivors of childhood cancer
}

\author{
Authors: \\ Tharina Guse \\ Gloria Eracleous 2 \\ Affiliations: \\ ${ }^{1}$ Department of Psychology, \\ University of Johannesburg \\ South Africa \\ ${ }^{2}$ Neuro-developmental \\ Clinic, Charlotte Maxeke \\ Academic Hospital, \\ Johannesburg, South Africa \\ Correspondence to: \\ Tharina Guse \\ Email: \\ tguse@uj.ac.za \\ Postal address: \\ PO Box 524, Auckland \\ Park 2006, South Africa \\ Dates: \\ Received: 25 Feb. 2010 \\ Accepted: 29 Sept. 2010 \\ Published: 28 Feb. 2011 \\ How to cite this article: \\ Guse,T. \& Eracleous, \\ G.,2011, 'Character \\ strengths of adolescent \\ survivors of childhood \\ cancer', Health SA \\ Gesondheid 16(1), \\ Art. \#544, 6 pages. \\ doi:10.4102/hsag.v16i1.544
}

(C) 2011. The Authors.

Licensee: OpenJournals Publishing. This work

is licensed under the

Creative Commons

Attribution License.
There is increased interest in possible positive outcomes for survivors of childhood cancer. This study investigated the manifestation of character strengths in adolescents who have survived cancer compared to that seen in healthy adolescents. The aim was to establish whether specific character strengths may be more prominent in adolescents who have survived cancer than in healthy adolescents. Two groups of participants, consisting of adolescents who have survived childhood cancer $(n=21)$ and a group of healthy adolescents $(n=21)$, were obtained through convenience sampling. They completed the Values in Action Inventory for Youth (VIAYouth) (Park \& Peterson 2006) as a measure of character strengths. No significant differences were found between the character strengths of adolescents who have survived cancer and their healthy peers, unlike the findings of a similar earlier study with adults (Peterson, Park \& Seligman 2006). It is concluded that the experience of serious illness such as cancer neither hindered nor enhanced the development of character strengths in this group of adolescent survivors. More research is needed to understand positive psychological functioning in the aftermath of childhood cancer.

Daar is toenemende belangstelling in moontlike positiewe uitkomste vir kinders wat kanker oorleef het. Hierdie studie het ondersoek hoe karaktersterktes na vore kom in adolessente wat as kinders met kanker gediagnoseer is in vergelyking met dié in ' $\mathrm{n}$ groep gesonde adolessente. Die studie het ten doel gehad om vas te stel of spesifieke karaktersterktes meer opvallend na vore kom in adolessente wat kanker oorleef het. Die deelnemers is deur middel van gerieflikheidsteekproefneming gekies. Die twee groepe het bestaan uit adolessente wat as kinders met kanker gediagnoseer is $(n=21)$ en ' $n$ groep gesonde adolessente $(n=21)$. Deelnemers het die Values in Action Inventory for Youth (VIA-Youth) (Park \& Peterson 2006) voltooi ten einde karaktersterktes te bepaal. Daar was geen beduidende verskil tussen die karaktersterktes van die adolessente wat kanker oorleef het en die gesonde groep nie, anders as met 'n soortgelyke vroeëre studie onder volwassenes (Peterson, Park \& Seligman 2006). Dit blyk dat die ervaring wat met ernstige siekte soos kanker gepaardgaan, ontwikkeling van karaktersterktes nóg bevorder nóg belemmer het in hierdie groep adolessente kankeroorwinnaars. Verdere navorsing is nodig om aspekte van positiewe sielkundige funksionering in adolessente kankeroorwinnaars te verstaan.

\section{Introduction}

A cancer diagnosis is a major event in a child's life, implying many psychological challenges. Survival rates of childhood cancer have increased dramatically in the last four decades (Robison et al. 2009:2308) and consequently many of these children enter adolescence in the aftermath of cancer treatment. Adolescence is a strenuous period during which several behavioural and social challenges occur. The experience of cancer in childhood may compound these challenges (Schultz et al. 2007:3649), often making it especially difficult to cope with the developmental tasks of adolescence. Higher survival rates have led to increased focus on the various outcomes of children who have survived cancer. Most research has focused on the negative physical and psychological outcomes of childhood cancer survival (Boman \& Bodegard 2000:105), specifically with regard to understanding the degree to which adolescents who have survived cancer experience distress and symptoms of psychopathology (Patenaude \& Kupst 2005:10-12).

Although negative sequelae, such as delayed achievement of psychosocial developmental milestones (Stam, Grootenhuis \& Last 2005:227), have been noted in adolescents who have survived childhood cancer, Patenaude and Kupst (2005:12) concluded that most studies have found little evidence of psychological maladjustment and that most survivors show good adjustment on psychological self-report measures. Further, some cancer survivors have reported some psychological benefits (Barraclough 1999:102). These positive outcomes include increased resilience and greater appreciation of life and relationships 
(Patenaude \& Kupst 2005:13). However, most research has been conducted with adult populations (e.g. Carver \& Antoni 2004:595-598; Peterson, Park \& Seligman 2006:1726; Tomich \& Helgeson 2004:16-23) or the parents of children with cancer (e.g. Barakat, Alderfer \& Kazak 2005:413-419; Fotiadou et al. 2008:401-409). Existing research on children and adolescent survivors suggest that there are many positive changes after successful cancer treatment (Kazak et al. 1996:365) and that adolescents often report posttraumatic growth as reflected in positive changes in self, relationships with others and plans for the future (Barakat et al. 2005:413). Some research even suggests that thriving (in a psychological sense) is a possible outcome of childhood cancer survival (Parry \& Chesler 2005:1055). Recently, Phipps (2007:1063) argued that more attention should be given to positive emotional states in research with this population. There clearly is an interest in more knowledge regarding possible positive outcomes following cancer survival. One positive outcome that has not been explored previously is the manifestation of particular strengths of character in adolescents who have survived cancer.

Character strengths can be viewed as positive traits reflected in an individual's thoughts, feelings and behaviours (Park, Peterson \& Seligman 2004:604). These traits can further be understood as measurable individual differences. Character strengths have received much attention in the field of positive psychology, which focuses on the scientific exploration of factors that allow individuals to thrive, as well as building on what is known about human resilience, strength and growth (Seligman 2002:5; Gable \& Haidt 2005:104). In order to specify important positive traits, Peterson and Seligman (2004) developed the Values in Action (VIA) classification. This is a specific model that describes, assesses and categorises 24

TABLE 1: VIA classification of character strengths (Peterson \& Seligman 2004).

\begin{tabular}{|c|c|}
\hline Virtue & Character strengths \\
\hline \multirow{5}{*}{$\begin{array}{l}\text { Wisdom: Cognitive strengths that entail the } \\
\text { acquisition of knowledge }\end{array}$} & Creativity \\
\hline & Curiosity \\
\hline & Open-mindedness \\
\hline & Love of learning \\
\hline & Perspective \\
\hline \multirow{4}{*}{$\begin{array}{l}\text { Courage: Emotional strengths that involve } \\
\text { the exercise of will to accomplish goals in } \\
\text { the face of opposition, external or internal }\end{array}$} & Authenticity \\
\hline & Bravery \\
\hline & Persistence \\
\hline & Zest \\
\hline \multirow[t]{3}{*}{ Humanity: Interpersonal strengths } & Kindness \\
\hline & Love \\
\hline & Social intelligence \\
\hline \multirow{3}{*}{$\begin{array}{l}\text { Justice: Civic strengths that underlie healthy } \\
\text { community life }\end{array}$} & Fairness \\
\hline & Leadership \\
\hline & Teamwork \\
\hline \multirow{4}{*}{$\begin{array}{l}\text { Temperance: Strengths that protect against } \\
\text { excess }\end{array}$} & Forgiveness \\
\hline & Modesty \\
\hline & Prudence \\
\hline & Self-regulation \\
\hline \multirow{4}{*}{$\begin{array}{l}\text { Transcendence: Strengths that forge } \\
\text { connections to the larger universe and } \\
\text { provide meaning }\end{array}$} & Humour \\
\hline & $\begin{array}{l}\text { Appreciation of beauty and } \\
\text { excellence Gratitude }\end{array}$ \\
\hline & Hope \\
\hline & Spirituality \\
\hline
\end{tabular}

valued character strengths with reference to six broad virtue classes. These strengths and virtue classes are presented in Table 1.

According to Peterson and Seligman (2004:19) crises may allow for a display of corrective strengths of character. Thus, it is possible that the experience of illness, viewed as a crisis, could lead to the development or emergence of specific character strengths. Peterson et al. (2006:17) reported that recovery from serious illness may be associated with character strengths such as appreciation of beauty, curiosity, bravery, forgiveness, humour and gratitude in adults. However, limited research exists regarding similar possible outcomes for adolescents who have survived illness.

In addition to specific character strengths, individuals also seem to possess signature strengths (Seligman 2002:5), which are the top five strengths as reflected on questionnaires that measure character strengths. More frequent and more conscious use of these strengths has been associated with a more fulfilling life (Seligman 2002:5; Seligman et al. 2005:419). If serious illness contribute to the development of specific character strengths, it is possible that those who have survived cancer may display specific signature strengths. Identifying signature strengths in adolescents who have survived childhood cancer may be beneficial in delivering psychosocial support to them and their parents, as it provides an avenue to instill hope and increase well-being.

\section{Problem statement}

Because limited information is available about positive outcomes for adolescents who have survived childhood cancer and, more specifically, with regard to the possible development of psychological strengths, the purpose of this research was to investigate the manifestation of character strengths in such adolescents. Findings from this study will add to the growing body of research on psychological strengths in general, their manifestation in adolescents and specifically their manifestation in the context of health and illness.

\section{Research design}

The purpose of this study was to investigate the manifestation of character strengths in adolescents who have survived cancer compared to character strengths displayed by healthy peers. The specific aim was to ascertain whether particular character strengths were more salient in adolescents who have survived cancer.

\section{Research approach and method}

This was a quantitative study and an ex post facto comparative design for independent groups was implemented. The two participant groups were matched according to age and gender to eliminate as many confounding variables as possible. Participants were also matched according to race owing to the finding by Van Eeden et al. (2008:150) that character strengths manifest differently in different population groups. 
TABLE 2: Demographic information of participants.

\begin{tabular}{ll}
\hline Variable & Frequency distribution of participants (\%) \\
\hline Age (years): & \\
13 & 4.8 \\
14 & 14.3 \\
15 & 33.3 \\
16 & 14.3 \\
17 & 9.5 \\
18 & 9.5 \\
19 & 14.3 \\
Race: & \\
African & 11.9 \\
White & 78.1 \\
Gender: & \\
Male & 52.4 \\
Female & 47.6 \\
\hline
\end{tabular}

Since the two groups were matched according to age, race and gender, demographic information is the same for both groups.

\section{Research population and sampling}

The 42 participants were adolescent volunteers between 13 years and 19 years of age, with a mean age of 16 years. Demographic information about the participants is shown in Table 2. The research group consisted of adolescent survivors of childhood cancer (cancer survivor group), while the control group consisted of healthy adolescents with no history of chronic medical illness (healthy group). Since the two groups were matched according to age, race and gender, Table 2 provides demographic information of all participants. Each group consisted of 21 participants, of whom 11 were male and 10 were female. The most prevalent diagnosis in the cancer survivor group was leukaemia (57\%), followed by lymphoma (19\%), bone tumours (19\%) and neuroblastoma $(4.8 \%)$.

Convenience sampling was used because the participants were selected on the basis of their willingness and availability to participate (Gravetter \& Forzano 2008:141). The small sample size was due to the generally small population of adolescent survivors of childhood cancer. Further, it was also extremely difficult to obtain participants who had survived childhood cancer and who were willing to participate in the study. Participants in the cancer survivor group were identified by approaching oncology wards and medical specialists at hospitals in Gauteng to obtain names of former patients who were in remission. The authors then contacted the patients' parents to request participation in the study.

Participants for the control group were selected in two ways. Firstly, the authors approached schools in Gauteng and obtained permission from the school principal for approaching volunteers who matched the participants of the experimental group with regard to age, race and gender for participation in the study. Secondly, adolescents and parents known to the researchers were approached and their consent for participation in the study was requested. The researchers were aware of possible selection bias resulting from this strategy. Therefore, results were interpreted cautiously, as suggeste d by Larzelere, Kuhn and Johnson (2004:300). However, Henry (1990:23) suggested that non-probability sampling, including convenience sampling, may be practical in exploratory research. A specific criterion for inclusion in the control group was the absence of any chronic illness. All participants had to be able to understand, speak, and read English.

\section{Research measuring instrument}

The VIA Inventory of Strengths for Youth (VIA-Youth) (Park \& Peterson 2006:891-909) was administered to determine character strengths in adolescents. It is a 198-item, self-report questionnaire that allows for a comprehensive survey of character strengths in youths between the ages of 10 and 17 years. Although some of the participants in the study were older than 17 years, the VIA-Youth was used for all participants as the adult scale differed from the youth version only with regard to language use. The items are clustered in 24 subscales, measuring the 24 character strengths in the VIA classification. The scale consists of 5-point Likert-style items and respondents have to indicate the applicable degree of the statements. The responses for each subscale are averaged to obtain a mean score, with higher numbers reflecting more of the strength (Peterson \& Seligman 2004:627). Scores for some items are calculated by reverse scoring. The VIA-Youth is usually completed online via the Internet but permission was obtained from the VIA Institute to use hard copies because not all the participants had Internet access.

Park and Peterson (2006:897) reported satisfactory alpha coefficients $(>0.70)$ and found that the scale has good stability and validity, as well as criterion-related validity as reflected in positive correlations between strengths and indices of psychological well-being. A recent study with South African youth yielded reliability indices of $0.92-0.96$ for the total scale (198 items) (Van Eeden et al. 2008:150). In the present study, Cronbach alpha coefficients ranged between 0.35 and 0.89 for the 24 individual strengths (Table 3).

The Cronbach alpha value of the total scale was 0.95 , which indicates acceptable internal consistency. The reliability coefficients for the six virtue classes were also satisfactory, ranging from 0.79 to 0.92 . However, not all of the 24 character strengths yielded satisfactory indices of internal consistency (curiosity, wisdom, leadership, prudence, forgiveness, social intelligence, self-regulation, modesty, appreciation of beauty and excellence). All other strengths showed satisfactory consistency of above 0.70 . These results were similar to those reported by Van Eeden et al. (2008:149) in a sample of South African adolescents. Consequently, the (nine) strengths with alpha coefficients below 0.70 were not included in further analyses.

Normality of score distributions was evaluated for the six virtues as well as the 15 strengths according to the ShapiroWilk test for normality (Table 4 ). The scores for all six virtues were normally distributed $(p>0.05)$. Normality distribution scores for the 15 character strengths were less consistent, although most of the character strengths showed $p$-values greater than 0.05 . Scores for the character strengths bravery, 
TABLE 3: Reliability indices associated with the 24 character strengths.

\begin{tabular}{ll}
\hline Character strength & Cronbach alpha coefficient \\
\hline Creativity & 0.77 \\
Curiosity & 0.69 \\
Perspective & 0.77 \\
Love of learning & 0.77 \\
Wisdom & 0.68 \\
Bravery & 0.84 \\
Authenticity & 0.78 \\
Persistence & 0.85 \\
Zest & 0.80 \\
Kindness & 0.74 \\
Love & 0.78 \\
Social intelligence & 0.35 \\
Fairness & 0.76 \\
Leadership & 0.66 \\
Teamwork & 0.80 \\
Forgiveness & 0.69 \\
Modesty & 0.50 \\
Prudence & 0.67 \\
Self-regulation & 0.43 \\
Appreciation of beauty and excellence & 0.58 \\
Gratitude & 0.80 \\
Hopew & 0.82 \\
Humour & 0.76 \\
Spirituality & 0.89 \\
\hline &
\end{tabular}

kindness, teamwork, gratitude, hope and spirituality were abnormally distributed $(p<0.05)$.

\section{Data collection and statistical analysis}

Participants completed the VIA-Youth in the presence of the second author and were guided regarding completion of the questionnaires. Their responses were manually scored and total scores were calculated for the 24 subscales measuring specific character strengths.

Descriptive statistics were obtained for both groups. Cronbach alpha reliability coefficients (Pallant 2007:95) were determined for the virtues wisdom, courage, humanity, justice, temperance and transcendence, as well as for the 24 character strength subscales of these virtues. Normality of the data was evaluated according to Shapiro-Wilk tests (Leung \& Austin 2006:282). The statistical significance of the differences between the character strengths of the two groups was determined by means of two-tailed $t$-tests and Mann-Whitney $U$ tests (Pallant 2007:220).

\section{Ethical considerations}

Permission for the study was obtained from the Ethics Committee of the Faculty of Science at the University of Johannesburg. Informed consent was subsequently obtained from the participants' parents or guardians. Since the parents of the experimental group's participants were very wary of possible negative implications for their children in the event of their participation in the study, their concerns were treated with the utmost respect and sensitivity. The authors spent time to address any concerns and provided parents with explicit information regarding the nature and aims
TABLE 4: Distribution characteristics of scores obtained with VIA-Youth scale.

\begin{tabular}{llllll}
\hline Character strength & $\begin{array}{l}\text { Mean } \\
\text { score }\end{array}$ & $\begin{array}{l}\text { Standard } \\
\text { deviation }\end{array}$ & Skewness & Kurtosis & $p$-value \\
\hline Creativity & 2.09 & 0.68 & 0.23 & -1.02 & 0.08 \\
Perspective & 2.24 & 0.70 & 0.56 & -0.21 & 0.08 \\
Love of learning & 2.06 & 0.68 & 0.51 & -0.40 & 0.16 \\
Bravery & 2.11 & 0.78 & 0.82 & 0.74 & $0.01^{*}$ \\
Authenticity & 2.36 & 0.77 & 0.23 & -0.30 & 0.51 \\
Persistence & 2.14 & 0.74 & 0.58 & -0.20 & 0.08 \\
Zest & 2.12 & 0.73 & 0.87 & 1.16 & 0.06 \\
Kindness & 2.12 & 0.71 & 1.47 & 4.37 & $0.00^{*}$ \\
Love & 1.99 & 0.72 & 0.37 & -0.70 & 0.07 \\
Fairness & 2.19 & 0.71 & 0.30 & 0.20 & 0.30 \\
Teamwork & 1.95 & 0.70 & 0.42 & -0.91 & $0.03^{*}$ \\
Gratitude & 1.79 & 0.66 & 1.70 & 3.73 & $0.00^{*}$ \\
Hope & 1.96 & 0.71 & 0.29 & -0.98 & $0.04^{*}$ \\
Humour & 2.11 & 0.73 & 0.28 & -0.27 & 0.25 \\
Spirituality & 1.82 & 0.88 & 1.24 & 1.37 & $0.00^{*}$ \\
\hline${ }^{*} p<0.05$. & & & & &
\end{tabular}

of the study. The participants' assent were also requested before completion of the questionnaires. Participation was voluntary and anonymity was ensured. All participants were provided the opportunity to receive feedback about their signature character strengths.

\section{Results and discussion}

Mean scores and associated standard deviations are shown in Table 5. The significance of differences between the manifestation of character strengths in the two groups is also reported. Significance of difference was determined according to both parametric techniques (two-tailed $t$-tests) and non-parametric techniques (Mann-Whitney $U$ tests) owing to the small sample size and because normality could not be assumed for all subscales.

The mean scores associated with the 15 character strengths did not differ significantly between the two groups, with $p$-values yielded by both the parametric ( $t$-tests) and nonparametric techniques (Mann-Whitney $U$ tests) being greater than 0.05 .

However, when the top five strengths displayed by each group were considered, interesting trends emerged. Signature strengths for each group are indicated by an asterisk $\left(^{*}\right)$ in Table 5. Although the mean scores associated with the different strengths were not significantly different between the two groups, the cancer survivors seemed to display a different constellation of signature strengths than the control group. In the cancer survivor group, the top five strengths were, in descending order, zest, perspective, fairness, authenticity and humour. The signature strengths of the control group were authenticity, perspective, kindness, persistence and fairness. Thus, while the groups shared the strengths authenticity, perspective and fairness, the top strength for the cancer survivor group was zest, compared to honesty for the control group. Whereas humour and zest were signature strengths for the cancer survivor group, they 
TABLE 5: Manifestation of character strengths among adolescent survivors of childhood cancer and healthy adolescents.

\begin{tabular}{|c|c|c|c|c|c|c|c|}
\hline \multirow[t]{2}{*}{ Virtue } & \multirow[t]{2}{*}{ Character strength } & \multicolumn{2}{|c|}{ Mean } & \multicolumn{2}{|c|}{ Standard deviation } & \multicolumn{2}{|c|}{$p$-value } \\
\hline & & Control group & $\begin{array}{c}\text { Cancer survivor } \\
\text { group }\end{array}$ & Control group & $\begin{array}{c}\text { Cancer survivor } \\
\text { group }\end{array}$ & $t$-test & $\begin{array}{c}\text { Mann-Whitney } \\
U \text { test }\end{array}$ \\
\hline \multirow[t]{4}{*}{ Wisdom } & & 2.21 & 2.17 & 0.52 & 0.53 & 0.83 & 0.81 \\
\hline & Creativity & 2.15 & 2.05 & 0.67 & 0.70 & 0.64 & 0.65 \\
\hline & Love of learning & 2.07 & 2.06 & 0.54 & 0.85 & 0.96 & 0.73 \\
\hline & Perspective & $2.21^{+}$ & $2.27^{+}$ & 0.66 & 0.75 & 0.78 & 0.95 \\
\hline \multirow[t]{5}{*}{ Courage } & & 2.21 & 2.15 & 0.49 & 0.70 & 0.76 & 0.47 \\
\hline & Authenticity & $2.55^{+}$ & $2.17^{+}$ & 0.77 & 0.73 & 0.11 & 0.15 \\
\hline & Bravery & 2.13 & 2.08 & 0.72 & 0.85 & 0.85 & 0.80 \\
\hline & Persistence & $2.19^{+}$ & 2.09 & 0.59 & 0.88 & 0.66 & 0.37 \\
\hline & Zest & 1.97 & $2.27^{+}$ & 0.61 & 0.82 & 0.20 & 0.34 \\
\hline \multirow[t]{3}{*}{ Humanity } & & 2.17 & 2.12 & 0.58 & 0.54 & 0.80 & 0.75 \\
\hline & Kindness & $2.19^{+}$ & 2.04 & 0.83 & 0.58 & 0.50 & 0.73 \\
\hline & Love & 2.02 & 1.96 & 0.81 & 0.66 & 0.78 & 0.80 \\
\hline \multirow[t]{3}{*}{ Justice } & & 2.20 & 2.24 & 0.63 & 0.51 & 0.84 & 0.84 \\
\hline & Fairness & $2.17^{+}$ & $2.21^{+}$ & 0.80 & 0.62 & 0.87 & 0.80 \\
\hline & Teamwork & 1.97 & 1.93 & 0.72 & 0.71 & 0.84 & 0.78 \\
\hline \multirow[t]{5}{*}{ Transcendence } & & 1.97 & 1.99 & 0.48 & 0.56 & 0.90 & 1.00 \\
\hline & Humour & 2.08 & $2.16^{+}$ & 0.73 & 0.74 & 0.72 & 0.67 \\
\hline & Gratitude & 1.85 & 1.74 & 0.75 & 0.56 & 0.61 & 0.90 \\
\hline & Hope & 1.99 & 1.93 & 0.60 & 0.82 & 0.76 & 0.56 \\
\hline & Spirituality & 1.81 & 1.83 & 0.81 & 0.97 & 0.93 & 0.95 \\
\hline
\end{tabular}

Degrees of freedom, 40

${ }^{\dagger}$, Signature strengths.

were replaced by persistence and kindness in the control group.

Several factors may explain the lack of differences between the two groups, with the first being the small sample size. Even in the study by Peterson et al. (2006:23), which involved 2087 adults, only small, although reliable, associations were found between history of physical illness and manifestation of specific character strengths. The small sample size of the current study may also have contributed to lower mean values than reported by Van Eeden et al. (2008:150). Another possible explanation could be that character strengths follow a developmental trajectory (Steen, Kachorek \& Peterson 2003:8) and may therefore not yet be as entrenched as in adulthood. However, perhaps the most plausible explanation may be that adolescents who have survived cancer are similar to healthy adolescents with regard to the manifestation of character strengths, just as they are similar with regard to general psychological adjustment and functioning (Patenaude \& Kupst 2005:11-12). The results can also be understood with reference to Mattsson, Lindgren and Von Essen's (2007:204) finding that cancer survivors do not differ from comparison groups with regard to positive outcomes such as relations with others and self. The lack of differences found in the current study further suggests that experience and subsequent survival of cancer may well not negatively affect character development.

Although not statistically significant, a trend towards a different constellation of signature strengths did emerge between the two groups. While the two groups shared authenticity, perspective and fairness as signature strengths, zest and humour were evident only in the cancer survivor group. Barraclough (1999:103) found that individuals who have survived cancer reported a stronger zest for life than before, which may partly explain why this specific strength emerged as top strength for the experimental group in this study. It is possible that the cancer survivors in this study embrace life more fully owing to the temporary loss of vitality during their illness. Consequently this attitude may become a particular strength to draw upon when dealing with life's challenges. Also, humour was one of the signature strengths of the cancer survivor group, but not of the control group. Existing literature lend some support to the possible role of humour in the experience of serious illness. Rocha (2001:112) contended that humour may be important in dealing with cancer and other life-threatening illnesses, while Peterson et al. (2006:23) also found humour to be amongst the strengths associated with adults who have recovered from physical illness. Therefore, investigation of this strength in the context of cancer survival may be an area for further exploration. Kindness and persistence were present as signature strengths only for the control group. However, this does not mean that these strengths were absent in the cancer survivor group; they were just not signature strengths. Finally, since the two groups shared three signature strengths, the results suggest that the groups may be more similar to each other that expected, confirming the findings by Mattsson et al. (2007:204).

\section{Limitations of the study}

Several limitations of this study should be taken into account. The small sample size may have contributed to the lack of differences found between the two groups. Further, since no longitudinal information was available for the participants of the experimental group, it is unknown whether there were some differences in character strengths before and during the illness. In addition, the study did not take duration of survival since diagnosis or remission into account, which might have 
shed more light on the lack of significant differences between the two groups' scores. The small number of participants also does not represent the general population and therefore no generalisations are possible. Finally, the possibility that other life-changing events, such as trauma or abuse, could have occurred in participants' lives has not been controlled for and could have influenced the results.

\section{Recommendations}

Firstly, further research with larger groups can be valuable to confirm and expand on the findings reported here. Research with regard to zest and humour specifically may shed light on how these positive constructs could influence psychological outcomes in the aftermath of childhood cancer. Secondly, a longitudinal approach could be beneficial to our understanding of the development of character strengths in adolescence. For example, the specific manifestation of character strengths could be measured in mid-childhood and then again during late adolescence. Such an approach may improve understanding about the development of character strengths not only through the experience of adverse situations such as physical illness or psychological trauma, but also through movement along the developmental trajectory. Finally, research that explores the manifestation of general psychological well-being in adolescent survivors of childhood cancer may yield valuable information on how different facets of well-being (e.g. life satisfaction, affect and optimal mental health or flourishing) may be related to the illness and its remission.

\section{Conclusion}

The broad aim of this study was to determine whether the manifestation of character strengths in adolescents who have survived cancer is different from that in healthy adolescents. Understanding of positive aspects of psychological outcomes for adolescent survivors of childhood cancer has, until recently, been neglected. The development of specific character strengths may be seen as one such outcome. Peterson et al. (2006:23) reported that adults who survived illness showed some character strengths to be relatively higher than those of healthy adults, and other researchers reported positive outcomes such as post-traumatic growth (Barakat et al. 2005:413-419), thriving (Parry \& Chesler 2005:1055) and flourishing (Phipps 2007:1063) to emerge in the aftermath of childhood cancer. A similar pattern was thus expected in this study. However, the results of this study did not support the hypothesis. There was no significant difference between the cancer survivor group and the healthy group with regard to either the six virtues or the 15 character strengths included in the statistical analyses. Thus, it seems that the manifestation of particular character strengths may not be a specific outcome for adolescents who have survived childhood cancer. However, it is important to point out that while this study suggests that there are no quantitative differences in the manifestation of character strengths among the two groups, qualitative differences may exist in the experience and manifestations of these strengths.

\section{References}

Barakat, L.P., Alderfer, M.A. \& Kazak, A.E., 2005, 'Posttraumatic growth in adolescent survivors of cancer and their mothers and fathers', Journal of Pediatric Psychology 31(4), 413-419. doi:10.1093/jpepsy/jsj058, PMid:16093518

Barraclough, J., 1999, Cancer and emotion, Wiley, New York.

Boman, K. \& Bodegard, G., 2000, 'Long-term coping in childhood cancer survivors: influence of illness, treatment and demographic background factors', Acto Pediatrica 89(1), 105-111. doi:10.1080/080352500750029167, PMid:10677068, Pediatrica 89(1), 105-111. doi:10.1080/080
doi:10.1111/j.1651-2227.2000.tb01197.x

Carver, C. \& Antoni, M., 2004, 'Finding benefit in breast cancer during the year after diagnosis predicts better adjustments 5 to 8 years after diagnosis', Health Psychology 23(6), 595-598. doi:10.1037/0278-6133.23.6.595, PMid:15546227

Fotiadou, M., Barlow, J.H, Powell, L.A. \& Langton, H., 2008, 'Optimism and psychological well-being among parents of children with cancer: an exploratory study', Psycho-Oncology 17, 401-409. doi:10.1002/pon.1257, PMid:17828706

Gable, L.G. \& Haidt, J., 2005, 'What (and why) is positive psychology'? Review of General Psychology 9(2), 103-110. doi:10.1037/1089-2680.9.2.103

Gravetter, F.J. \& Forzano, L.B., 2008, Research methods for the behavioral sciences, Wadsworth, Belmont.

Henry, G.T., 1990, Practical sampling, Sage, London.

Kazak, A.E., Stuber, M.L., Barakat, L.P. \& Meeske, K., 1996, 'Assessing posttraumatic stress related to medical illness and treatment: the Impact of Traumatic Stressors Interview Schedule (ITSIS)', Families, Systems and Health 14(3), 365-380. doi:10.1037/h0089795

Larzelere, R.E., Kuhn, B.R. \& Johnson, B. 2004, 'The intervention selection bias: An underrecognized confound in intervention research', Psychological Bulletin 130, 289-303. doi:10.1037/0033-2909.130.2.289, PMid:14979773

Leung, F.T.L. \& Austin, J.T., 2006, The psychology research handbook, Sage, London.

Mattsson, E., Lindgren, B. \& Von Essen, L., 2007, 'Are there any positive consequences of 'childhood cancer?' Acta Oncologica 47, 199-206. doi:10.1080/02841860701765667, PMid:18210296

Pallant, J., 2007, SPSS survival manual, 3rd edn., Open University Press, Berkshire.

Park, N. \& Peterson, C., 2006, 'Moral competence and character strengths among adolescents: The development and validation of the Values in Action Inventory of strengths for youth', Journal of Adolescence 29, 891-909. PMid:16766025

Park, N., Peterson, C. \& Seligman, M.P., 2004, 'Strengths of character and wellbeing', Journal of Social and Clinical Psychology 23, 603-619. doi:10.1521/ jscp.23.5.603.50748, doi:10.1521/jscp.23.5.628.50749

Parry, C. \& Chesler, M.A., 2005, 'Thematic evidence of psychosocial thriving in childhood cancer survivors', Qualitative Health Research 15(8), 1055-1073. doi:10.1177/1049732305277860, PMid:16221879

Patenaude, A.F. \& Kupst, M.J., 2005, 'Psychosocial functioning in pediatric cancer', Journal of Pediatric Psychology 30(1), 9-27. doi:10.1093/jpepsy/jsi012, PMid:15610981

Peterson, C., Park, N. \& Seligman, M.E.P., 2006, 'Greater strengths of character and recovery from illness', Journal of Positive Psychology 1, 17-26. doi:10.1080/17439760500372739

Peterson, C. \& Seligman, M.E.P., 2004, Character strengths and virtues: A handbook and classification, Oxford University Press, New York.

Phipps, S., 2007, 'Adaptive style in children with cancer: Implications for a positive psychology approach', Journal of Pediatric Psychology 32(9), 1055-1066. doi:10.1093/jpepsy/jsm060, PMid:17698880

Robison, L.L., Armstrong, G.T., Boice, J.D., Chow, E.J., Davies, S.M., Donaldson, S.S et al., 2009, 'The Childhood Cancer Survivor Study: A National Cancer Institutesupported resource for outcome and intervention research', Journal of Clinical Oncology 27(14), 2308-2318. doi:10.1200/JCO.2009.22.3339, PMid:19364948, PMCid:2677920

Rocha, T.L., 2001, Coping when someone in your family has cancer, Rosen Publishing Group, New York.

Schultz, K.A., Ness, K.K., Whitton, J., Recklitis, C., Zebrack, B., Robison, L.L. et al., 2007 'Behavioral and social outcomes in adolescent survivors of cancer: A report from the Childhood Cancer Survivor Study', Journal of Clinical Oncology 25, 3649-3656. doi:10.1200/JCO.2006.09.2486, PMid:17704415

Seligman, M.E.P., 2002, 'Positive psychology, positive prevention, and positive therapy', in C.R. Snyder \& S.J. Lopez (eds.), Handbook of positive psychology, pp. 3-9, Oxford University Press, New York.

Seligman, M.E.P., Steen, T.A., Park, N., \& Peterson, C., 2005, 'Positive psychology progress: empirical validation of interventions', American Psychologist 60, 410421. doi:10.1037/0003-066X.60.5.410, PMid:16045394

Stam, H., Grootenhuis, M.A. \& Last, B.F., 2005, 'The course of life of survivors of childhood cancer', Psycho-Oncology 14, 227-238. doi:10.1002/pon.839, PMid:15386772

Steen, T.A., Kachorek, L.V. \& Peterson, C., 2003, 'Character strengths among youth', Journal of Youth and Adolescence 32, 5-16. doi:10.1023/A:1021024205483

Tomich, P. \& Helgeson, V., 2004, 'Is finding something good in bad news always good? Benefit finding among women with breast cancer', Health Psychology 23, 16-23. doi:10.1037/0278-6133.23.1.16, PMid:14756599

Van Eeden C., Wissing M.P., Dreyer, J., Park, N. \& Peterson, C., 2008, 'Validation of the Values in Action Inventory of Strengths for Youth (VIA-Youth) among South African learners', Journal of Psychology in Africa 18, 143-154. 